\title{
Avian Frugivory and seed dispersal of Batangi in District Haripur, KPk, Pakistan
}

\author{
Saira Bibi*, Muhammad Fiaz khan and Aqsa Rehman \\ Department of Zoology, Hazara University, Mansehra, KPK, Pakistan
}

*Corresponding author: Saira Bibi, Department of Zoology, Hazara University,

Mansehra, KPK, Pakistan.

Received Date: June 08, 2020

Published Date: June 24, 2020

\begin{abstract}
Study was conducted in village chhajjian. A total of 200 birds were recorded to visit the Batangi fruites during the survey belonging to eight species in different localities of district Haripur, as most of these trees were found in village chhajjian so the highest amount of the visitors were recorded in this area. These included three species of Brahminy Starling Sturnus pagodarum, bulbuls, Pycnonotus sp., Common Myna Acridotheres tristis, Asian Koel Eudynamys scolopacea, White-headed Babbler Turdoides affnis and Small Green-Billed Malkoha Phaenicophaeus viridirostris. Highest proportion of feeding visits was contributed by Red whiskered Bulbul, Pycnonotus jocosus (21.3\%) also we recorded the yellow and red vented bulbul to forage on these trees.
\end{abstract}

Keywords: Frugivores; Dispersal; Pyrus pashia

\section{Introduction}

Pyrus pashia belong to the family Rosaceae [1] based on geographic distribution it is divided into Occidental and Oriental pears [2]. Including China, Japan, and the Korean Peninsula, The majority of Oriental pears are native to East Asia, while Occidental pears are to Europe, North Africa, Asia Minor, Iran, Central Asia, and Afghanistan. Besides displaying high resistance to stress, they are important germ plasm resources for genetic breeding of pears. However, due to the ecological damage caused by global warming and urbanization many of these wild populations are in danger. Grazing, Fire and exploitation of the wood for furniture, carving and oil are threatening the species [3]. The pulp of fleshy fruits, with the edible, soft, nutritious tissues surrounding the seeds is a primary food source for many animals, notably birds and mammals [4]. Away from the parent plants these animals regurgitate, defecate, spit out or otherwise drop the undamaged seeds; in natural communities they are the seed dispersers that establish a dynamic link between the fruiting plant and the seed-seedling bank [5]. In most ecosystems Avian frugivores are considered as the most important seed dispersers [6]. Seed predator's animals are Parrots, some pigeons and finches [7]. For identifying the roles of individual disperser species play in plant recruitment dynamics, the study of interactions between avian frugivores and plant including conservation and restoration is important thus having implications for both theoretical understanding of mutualisms, species interactions and for applied work, [8]. So, the keeping in view the importance of these plants we conducted this study to assess the role of different frugivores in the seed spreading in district Haripur.

\section{Materials and Methods}

\section{Study area}

Study area was conducted in the district Haripur KPk Pakistan. Haripur is the main city of the Haripur District in Hazara, Khyber 
Pakhtunkhwa in Pakistan, with Swabi and Buner to the west, some $65 \mathrm{~km}$ north of Islamabad and $35 \mathrm{~km}$ south of Abbottabad. It is in a hilly plain area at an altitude of $520 \mathrm{~m}$. Having the $33.9946^{\circ} \mathrm{N}$, $72.9106^{\circ} \mathrm{E}$. With the pleasant weather and hilly areas with grasses and pine trees (Figure 1).

Figure 1: Map of District Haripur.

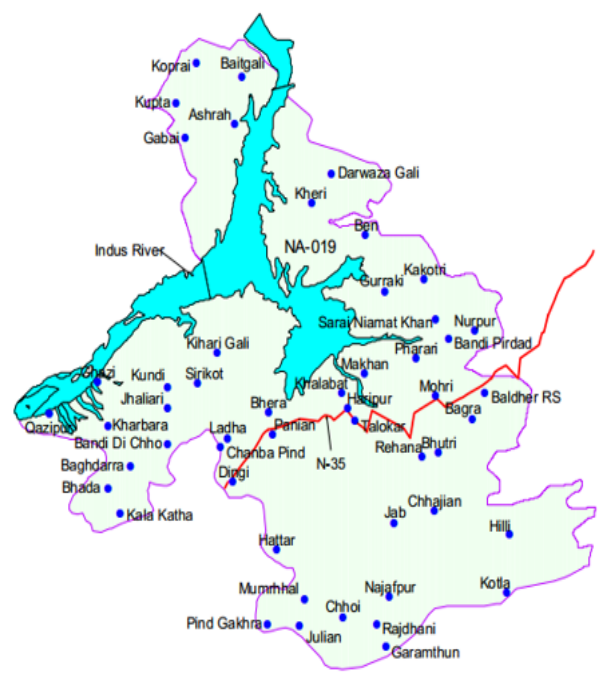

\section{Methodology}

Study was conducted as a field survey during the complete year 2018. Trees with ripe fruits were selected. By the observer a pair of binoculars was used, usually 10-15 m away who sat near the tree and watched the canopy for recording animal visits. During the prolonged watches, the observer noted the visitor (bird/mammal), name, fruit-feeding frequency visits by different species, and fruit handling behaviour (whether fruit ingested whole or only partly seeds dropped and eaten). Bird's names were known by literature.

\section{Results and Discussion}

A total of 200 birds were recorded to visit the Batangi fruites during the survey belonging to eight species in different localities of district Haripur, as most of these trees were found in village chhajjian so the highest amount of the visitors were recorded in this Table 1: Different visitor of Batangi fruites in different areas of district Haripur.

\begin{tabular}{|c|c|c|c|c|}
\hline \multicolumn{5}{|c|}{ Feeding Visits } \\
\hline Common Name & Scientifc Name & Number & Percentage & Locations \\
\hline Brown-headed Barbet & Megalaima zeylanica & 28 & 12.9 & chhajjian \\
\hline Small Green-billed Malkoha & Phaenicophaeus viridirostris & 36 & 16.59 & chhajjian \\
\hline Red-vented Bulbul & Pycnonotus cafer & 25 & 11.52 & chhajjian \\
\hline Red-whiskered Bulbul & Pycnonotus jocosus & 28 & 12.9 & dana \\
\hline White-browed Bulbul & Pycnonotus luteolus & 21 & 9.68 & seria \\
\hline Common Myna & Acridotheres tristis & 37 & 17.05 & chhajjian \\
\hline Brahminy Starling & Sturnus pagodarum & 38 & 17.51 & chhajjian \\
\hline Asian Koel & Eudynamys scolopacea & 4 & 1.84 & chhajjian \\
\hline white tree piee & Urocissa erythrorhyncha & 9 & 10.2 & Haripur \\
\hline yellow tree piee & Dendrocitta vagabonda & 20 & 8.12 & Haripur \\
\hline
\end{tabular}

area. These included three species of Brahminy Starling Sturnus pagodarum, bulbuls, Pycnonotus sp., Common Myna Acridotheres tristis, Asian Koel Eudynamys scolopacea, White-headed Babbler Turdoides affnis and Small Green-Billed Malkoha Phaenicophaeus viridirostris. Highest proportion of feeding visits was contributed by Red whiskered Bulbul, Pycnonotus jocosus (21.3\%) also we recorded the yellow and red vented bulbul to forage on these trees followed by White-headed Babbler (17.7\%) and Asian Koel (19.3\%). Among the various avian families, Pycnonotidae (bulbuls) made the majority of the visits (45.6\%), even though when these trees were flowering these species were frequently found, followed by Sturnidae (mynas) (22.6\%). Brown-headed Barbet Megalaima zeylanica was also found in different localities of district Haripur (Table 1). 
The whole fruit was swallowed by the birds, Asian Koel, Brownheaded Barbet, Mynas, Starlings and Indian Grey Hornbill. Most often, in piecemeal bulbuls ate the fruit and dropped the seeds under the canopy itself. Occasionally, small fruits were swallowed by them. During the study period in chhajjian the 350 birds belonging to three species visited the focal tree. Among the frugivorous birds, the highest proportion of visits was made by the Asian Koel (55.4\%) followed by Common Myna (40.6\%), and Rose-ringed Parakeet Psttacula krameri (10\%). To eat fruit In addition to birds, grey squirrels also visited the plant. While myna and koel used up the whole fruit, parakeets ate the seeds. Birds constituted the principal seed dispersers. Except squirrels o other mammals were foraging. Most of the natural seedlings of sandal were foundgrowing in the middle of thorny bushes, where the birds seem to have dropped the seeds. Birds that are benefcial to sandalwood dispersal and regeneration were Koel, Common Myna, Brahminy Starling, Brownheaded Barbet, and White-headed Babbler. These species visited the fruit crop more frequently and swallowed the fruit wholly. Hence, these species could be considered as major seed dispersers. Asian Koel seems to have preference to sandal fruits. Due to their smaller beak and narrow gape Bulbuls could not swallow the whole fruit. They appear to play a minor role only. In seed dispersal Parakeets did not play any role. They consumed the fruits mainly to digest the seeds and hence considered as seed predators. Greenbilled Malkoha made very few visits, thus contributing only a minor role. Sustaining the Asian Koel population will ensure the renewal of trees in the forests. Seed dispersing bird species such as koel
Efforts need to be undertaken to provide a healthy habitat, as the population of tree is drastically dwindling in the wild.

\section{Acknowledgment}

I would like to acknowledge my parents.

\section{Conflict of Interest}

No conflict of interest.

\section{References}

1. Potter D, Eriksson T, Evans RC, Oh S, Smedmark JEE, et al. (2007) Phylogeny and classification of Rosaceae. Plant systematics and evolution 266(1-2): 05-43.

2. Bao L, Kunsong C, Dong Z, Xiugen L, Yuanwen T (2008) An assessment of genetic variability and relationships within Asian pears based on AFLP (amplified fragment length polymorphism) markers. Scientia Horticulturae 116(4): 374-380.

3. Marcotullio PJ (2003) Globalisation, urban form and environmental conditions in Asia-Pacific cities. Urban Studies 40(2): 219-247.

4. Howe HF (1986) Seed dispersal by fruit-eating birds and mammals. Seed dispersal 123: 189.

5. Saller CF, Salama AI (1993) Seroquel: biochemical profile of a potential atypical antipsychotic. Psychopharmacology 112(2-3): 285-292.

6. McCarty JP, Douglas JL, Cathryn HG, Sarah S (2002) Spatial and temporal variation in fruit use by wildlife in a forested landscape. Forest Ecology and Management 164(1-3): 277-291.

7. Corlett RT (1998) Frugivory and seed dispersal by birds in Hong Kong shrubland. Forktail 13: 23-27.

8. Loiselle BA, JG Blake (1999) Dispersal of melastome seeds by fruiteating birds of tropical forest understory. Ecology 80(1): 330-336. 